\title{
EVIDENCE: ADMISSIBILITY OF NEWSPAPERS UNDER THE HEARSAY RULE
}

\section{$\mathrm{N}$} EWSPAPERS OFFERED in evidence as proof of the facts recited therein are out-of-court declarations generally held to be inadmissible under the hearsay rule. ${ }^{1}$ However, in a recent decision, the Court of Appeals for the Fifth Circuit held that an exception to this exclusionary rule will be made where the evidence in question is necessary and the circumstances under which the declaration was made provide guarantees of trustworthiness.

In Dallas County v. Commercial Union Assur. Co., ${ }^{2}$ a county in Alabama, following the collapse of its courthouse on July 7, 1957, sought to recover on a lightning insurance policy, contending that the collapse was caused by lightning which had struck the courthouse on July 2. The plaintiff attributed char in the debris to lightning. Denying liability, the defendant claimed that lightning had not struck the courthouse and that the collapse was caused by structural weaknesses. ${ }^{3}$ To explain the presence of char, the defendant introduced expert testimony indicating a fire at some earlier date and offered in evidence a June 9, I90I, copy of the local newspaper, which contained an anonymous article reporting a fire in the then unfinished tower. ${ }^{4}$ The federal district judge admitted the document as "part of the records"s of the newspaper company over the plaintiff's objection that this was hearsay evidence.

On appeal from judgment on a jury verdict for the defendant, the plaintiff assigned as error the admission of the newspaper into evidence.

\footnotetext{
${ }^{1}$ Watford v. Evening Star Newspaper Co., 21 I F.2d 3 I (D.C. Cir. 1954); Bebbington v. California W. States Life Ins. Co., 30 Cal. 2d 157, 180 P.2d 673 (1947); State v. Otis Elevator Co., 10 N.J. 504, 92 A.2d 385 (1952) (alternative rationale); State v. King County, 29 Wash. 2d 37, 185 P.2d 134 (1947); Hamachek v. Duvall, I35 Wis. 108, II N N.W. 634 (1908).

2286 F.2d 388 (5th Cir. 1961).

${ }^{3}$ The defendant contended that "the collapse of the tower was caused by structural weaknesses attributable to a faulty design, poor construction, gradual deterioration of the structure, and overloading brought about by remodeling and the recent installation of an air-conditioning system, part of which was constructed over the courtroom trusses." Id. at 390 .

"The defendant authenticated the newspaper by testimony of the editor of a successor newspaper company that the company maintained archives of its own and its predecessor's issues and that the issue in question was from those archives. Id. at $39 \mathrm{I}$.

${ }^{5} I b i d$.
} 
The Court of Appeals affirmed, noting that "the law governing hearsay is somewhat less than pellucid." Preferring not to "characterize this newspaper as a business record, ${ }^{7}$ nor as an ancient document, ${ }^{8}$ nor as any other readily identifiable and happily tagged species of hearsay exception," the court held the newspaper admissible because "it is necessary and trustworthy, relevant and material, and its admission is within the trial judge's exercise of discretion in holding the hearing in bounds."10

The Court of Appeals stated that it could find no cases clearly on point but observed that "there is no procedural canon against the exercise of common sense in deciding the admissibility of hearsay evidence."11 Therefore, the court declared that it would apply general principles of relevancy and materiality, being guided in its deliberations by Rule 43(a) of the Federal Rules of Civil Procedure, which "affirmatively expands the scope of admissibility."12 Utilizing this approach, the court was able to base its decision upon an examination of the fundamental

'Id. at 392 .

7 The Federal Business Records Act, 28 U.S.C. $\$$ I732 (r958), read literally would seem to permit the admission of a newspaper as a "business record" of the newspaper publishing company. Apparently, this is the basis on which the trial judge admitted the newspaper in the instant case. See note 5 supra. No cases deciding this question have been discovered, and the defendant did not urge this position as a ground for affirmance. Brief for Appellee, p. 32.

The analogous problem of admitting mercantile credit reports as "business records" of the credit reporting agency is discussed in 44 MINN. L. REv. 7I9 (1950), citing Moran v. Pittsburgh-Des Moines Steel Co., I 83 F.2d 467 (3d Cir. 1950), and Davis v. Louisville Trust Co., 18 × Fed. Io (6th Cir. I9 10).

${ }^{8}$ Wigmore limits the ancient documents exception to deeds. 5 WIGMORE, EvidENCE $\S 1573$ ( $3 \mathrm{~d}$ ed. 1940) [hereinafter cited as WIGMORE]. UNIFORM RULE OF EvideNCE $6_{3}(29)$ restricts it to "recitals in documents affecting property." The cases, however, do not support such a narrow proposition of law. See cases cited note I 7 infra; Wickes, Ancient Documents and Hearsay, 8 TEXAs L. REV. 45 I (1930) 3 Note, 46 IowA L. REV. 448 ( $196 \mathrm{I})$.

On appeal, the defendant placed great emphasis on a similar, but loosely-defined, exception permitting proof of ancient community facts. Brief for Appellee, pp. 42-48. Counsel for appellee called attention to Trustees of German Township v. Farmers \& Citizens Sav. Bank Co., I ${ }_{3}$ N.E.2d 409 (C.P. Ohio), aff'd per curiam, i 5 N.E.2d 690 (Ct. App. Ohio 1953), which admitted an old community newspaper as proof of a lease of a portion of the courthouse. The trial court deemed the age of the newspaper as satisfying authentication requirements and took judicial notice of the "public matters" reported therein.

286 F.2d at 397 .

${ }^{10}$ Ibid.

${ }^{11}$ Ibid.

${ }^{12}$ Id. at 394. "In a federal court the rule, whether federal or state, which favors the reception of the evidence governs." New York Life Ins. Co. v. Schlatter, 203 F.2d 184, I88 (5th Cir. 1953). See Green, Federal Civil Procedure Rule 43(a), 5 VAND. L. REV. 560 (1952). 
rationale of the hearsay rule and the factors justifying an exception therefrom..$^{13}$

The strongest objection to the admission of hearsay evidence is that the offeror's opponent has no opportunity to cross-examine the original declarant. ${ }^{14}$ Therefore, the opponent cannot test the declarant's perception, correctness and comprehensiveness of memory, power of intelligible expression, and sincerity. ${ }^{15}$ However, where these testimonial dangers are not present because of the circumstances under which the declaration was made and where the ascertainment of truth would be greatly aided by relevant and material testimony, exceptions to the exclusionary hearsay rule have been recognized. Thus, Wigmore has pointed out that each established exception to the hearsay rule does satisfy in varying degrees, the prerequisites of necessity for the evidence and circumstantial guarantee of its trustworthiness. ${ }^{16}$

${ }^{13}$ The court quoted extensively from G. \& C. Merriam Co. v. Syndicate Pub. Co., 207 Fed. 515 (2d Cir. 1913), as indicative of the approach it would take in deciding the instant case. In the Merriam case Learned Hand, U.S.D.J., admitted recitals in an old dictionary preface on the basis of Wigmore's requisites for an exception to the hearsay rule. The reported case was the affirmance of this decision by the Second Circuit, setting out Judge Hand's opinion in full.

14 NLRB v. Imparato Stevedoring Corp., 250 F.2d 297 (3d Cir. 1957) (dictum); Buchanan v. Nye, 28 Cal. App. 2d 582, 275 P.2d 767 (1954); Colgrove v. Goodyear, 325 Mich. 127, 37 N.W.2d 779 (1949).

Other objections sometimes asserted against the admission of hearsay evidence arc that the declaration was not made under oath and that the jury cannot observe the demeanor of the original declarant. Wigmore regards the lack of oath as merely an accompaniment of the fact that in a trial the declarant may be subjected to crossexamination. 5 WIGMORE $\S 1362$. McCormick, however, belicves that the objection has some merit in that the taking of an oath is a ceremonial and religious act inducing the witness to realize the solemnity of the occasion and hence to tell the truth. MCCoRMICK, EvidENCE § 224 (1954) [hereinafter cited as McCorMICK].

Any exception to the hearsay rule deprives the jury of an opportunity to observe the demeanor of the original declarant. There must, therefore, be factors favoring admissibility which offset this objection.

${ }^{15}$ Morgan, Hearsay Dangers and the Application of the Hearsay Concept, 62 HARv. L. REv. 177, 218 (1948). Morgan points out, however, that "in the vast majority of lawsuits its principal utility will be in limiting or eliminating the danger of deception through faults in memory and perception." Id. at I88. McCormick agrees with Morgan's view of the restricted purpose of cross-examination in most lawsuits. McCorMICK $§ 225$.

${ }_{10} 5$ WIGMORE $\S$ I 420 . These principles advanced by Wigmore have frequently been given judicial recognition. E.g., United States v. Wescoat, 49 F.2d 193 (4th Cir. 1931); Whittaker v. Thornberry, $306 \mathrm{Ky} .830,209$ S.W.2d 498 (1948); Potter v. Baker, 162 Ohio St. 488, 124 N.E.2d 140 (1955). McCormick suggests the analogous requirements of necessity, accuracy of transmission, and reliability. MCCORMICK $\S 301$.

One writer has pointed out:

"[I]n some of the exceptions the first one of the principles has been chiefly in mind, 
The requirement of necessity for the evidence is most emphasized in those exceptions admitting facts recited in ancient documents ${ }^{17}$ and declarations as to ancient boundaries ${ }^{18}$ or matters of family, ${ }^{10}$ community, and general history. ${ }^{20}$ The admission of such evidence is usually deemed "necessary" only because of the death or unavailability of the original declarant at the time of trial. Yet, only "reasonable inconvenience" is required for some types of hearsay declarations affording an unusually strong guarantee of trustworthiness. ${ }^{21}$

while in other exceptions the second principle is emphasized. In some of the exceptions one of these principles is almost entirely lacking. It thus appears that the principles mutually supplement one another. Where one is weak, the other may serve in some measure to take its place. It is not essential to a hearsay exception that there be both an element of urgent necessity and a strong guarantee of trustworthiness."

Wickes, Ancient Documents and Hearsay, 8 TEXAs L. REv. 45I, 462 (1930).

${ }^{17}$ Ussery v. Anderson-Tully Co., 122 F. Supp. I15 (E.D. Ark. 1954); Board of Educ. v. Unknown Heirs, 128 N.E.2d 534 (C.P. 1954), aff'd, 99 Ohio App. 463, 134 N.E.2d 872 (1955). The requirement that a document be at least thirty years old, MCCORMICK $\S 298$, is also a factor tending to assure trustworthiness because of the probable lack of any motive to deceive since the declaration was made before the beginning of any litigation. UNIFORM RULE OF EVIDENCE 63 (29), however, does not require that the document be "ancient."

The courts frequently fail to distinguish the ancient documents rule concerned with authentication of evidence from the rule that is the exception to the hearsay rule. E.g., Brown v. Weare, 348 Mo. 135,152 S.W.2d 649 (1941); Commonwealth ex rel Ferguson v. Ball, 277 Pa. 3 or, 121 Atl. 191 (1923); Bruni v. Vidaurri, 140 Texas 138 , I66 S.W.2d 8I (1942). Contra, Town of Ninety Six v. Southern Ry., 267 F.2d 579 (4th Cir. 1959); Skipper v. Yow, 240 N.C. I02, 81 S.E.zd 200 (1954); Robinson v. Peterson, 200 Va. 186, 104 S.E.2d 788 (1958). This is understandable in that the same principles of necessity and circumstantial guarantee of trustworthiness underlie both rules of evidence.

${ }^{18}$ Minor v. Fincher, 206 Ga. 721,58 S.E.2d 389 (1950); Hail v. Haynes, $3 \times 2$ Ky. 357, 227 S.W.2d 918 (1950); Owens v. Blackwood Lumber Co., 212 N.C. r33, r93 S.E. $2 \times 9$ (1937). Some cases do not require that the reputation be "ancient," but that it be the "best evidence." Minneapolis \& St. Louis Ry. v. Ellsworth, 237 Minn. 439, 54 N.W.2d 800 (1952); Kardell v. Crouch, 326 S.W.2d 869 (Tex. Civ. App. 1959). Neither is required by UNIFORM RULE of EvideNCE $63(27)(a)$, which relies only on factors assuring trustworthiness.

${ }^{10}$ The majority rule requires that the declarant be deceased. Miami County Nat'l Bank v. Bancroft, I2r F.2d 921 (Ioth Cir. r941); Ellis v. Dixon, $294 \mathrm{Ky}$. 609, 172 S.W.2d 46I (1943); Foulkes v. Chicago Title \& Trust Co., 283 Ill. App. 142 (I935). UNIFORM RULE OF EVIDENCE 63 (24) requires that the declarant be "unavailable."

${ }^{20}$ Montana Power Co. v. FPC, I85 F.2d 49x (D.C. Cir. 1950), cert. denied, 340 U.S. 947 (195 I) (dictum); International Free \& Accepted Modern Masons v. Most Worshipful Prince Hall Grand Lodge, 318 S.W.2d 46 (Ky. 1958); Board of Educ. v. Unknown Heirs, 128 N.E.2d 534 (C.P. 1954), aff'd, 99 Ohio App. 463,134 N.E.2d 872 (1955). UNIFORM RULE OF Evidence $63(27)(\mathrm{b})$ does not require that the reputation be "ancient."

${ }_{21}$ Thus, Wigmore points out that authors of commercial lists and market quotations, learned treatises, hospital records, and official documents clearly are deemed "unavail- 
The established exceptions to the hearsay rule also provide, in varying degrees, circumstantial guarantees of trustworthiness. Under many exceptions the declaration must have been made at a time when there was no apparent motive to deceive ${ }^{22}$ or when there was such notoriety as to have made the success of any attempted deception doubtful. ${ }^{23}$ Accuracy in memory and transmission is especially assured in exceptions involving written instruments, as the declaration usually was recorded at a time near the event. ${ }^{24}$ However, some exceptions, especially those concerning proof by reputation, give little assurance of accuracy in perception and, indeed, often involve multiple hearsay. ${ }^{25}$

able" because of death or absence from the jurisdiction. But the necessity requirement is also satisfied by the mere "practical inconvenience" that would be caused if the writers were required to appear. 6 WIGMORE $\S$ i 700 .

${ }^{22}$ Declarations as to family pedigree are deemed trustworthy because they were "natural effusions" of the declarant. Whitelocke v. Baker, 13 Ves. Jr. 510, 514, 33 Eng. Rep. 385, 386 (Ch. 1807).

To be admissible, declarations of reputation as proof of boundaries and family pedigree must have been made ante litem motam. Owens v. Blackwood Lumber Co., 212 N.C. 133,193 S.E. 2 19 (1937).

Business records must have been made in the "regular course of business." UNIFORM RULE OF EvideNCE 63(13); Federal Business Records Act, 28 U.S.C. \& 1732 (1958).

Dying declarations are admissible in criminal actions only if the declarant was solemnly aware of approaching death. Batten v. Commonwealth, 190 Va. 235, 56 S.E.2d 23 I (1949). The "sincerity" requirement is the strongest factor in this exception, as "necessity" is deemed to be present even though there is corraborative testimony available. Ryan, Dying Declarations in Civil Actions, so B.U.L. REv. 470 (1930) 5 WIGMORE $\&$ I 435 .

${ }^{23}$ Several exceptions to the hearsay rule give a circumstantial guarantee of trustworthiness in that the assertions were made for other persons to rely on and, if false, probably would have been exposed. Laughlin, Business Entries and the Like, 46 IowA L. REv. 276, 289 (196x) (business records); 6 WIGMORE $§$ 1704 (standard price lists and market quotes).

Board of Educ. v. Unknown Heirs, 128 N.E.2d 534 (C.P. 1954), aff'd, 99 Ohio App. 463,134 N.E.2d 872 (1955), is representative of cases admitting local histories as proof of historical facts of "general and public notoriety." Wignore believes that this exception has sometimes been too narrowly construed, resulting in the exclusion of county histories. 5 WIGMORE $§ \times 598$.

${ }^{24}$ This would seem to be a strong factor favoring the adınission of business records. See Standard Oil Co. v. Moore, 251 F.2d 188 (9th Cir. x957), cert. denied, 356 U.S. 975 (1958); United States v. Wescoat, 49 F.2d 193 (4th Cir. 1931); 5 Wigmore $\S 1526$.

While other exceptions involving written instruments do not require that the decla. ration be reduced to writing at a time near to the event in question, this usually will have been the case and, in any circuinstance, will be closer in time to the event narrated than is the trial.

${ }^{25}$ Upon analysis exceptions admitting reputation as to family pedigree and local history will all involve, on occasion, multiple hearsay, for all of these exceptions are based upon the passing of "word-of-inouth" assertions from generation to generation. But these well-established exceptions are justified by balancing this danger against other 
The standards of necessity and trustworthiness are the result of an effort to rationalize hearsay rule exceptions perhaps originating more in experimentation than in logical analysis. Yet, the origin of these standards in no way weakens their validity as guidelines for future consideration of evidence which does not fit comfortably within an established exception, but which may merit admission when viewed from an analytical and common sense perspective. Indeed, an analysis based on necessity and trustworthiness is preferable to a technical consideration of whether an established exception might plausibly be expanded to justify the admission of evidence. In utilizing the latter approach, a court may fail to reach basic considerations. It thus may reject meritorious evidence or admit evidence which does not offer protection from defects usually guarded against by cross-examination.

Refusing to resort to traditional hearsay labels, the Court of Appeals in the Dallas County decision employed basic analysis, and its approval of the admission of the newspaper seems a sound result in light of the circumstances presented in the case. A strong element of necessity was present because the court was seeking to ascertain facts concerning an event supposed to have taken place a half-century before. While the newspaper technically may have involved multiple hearsay, ${ }^{26}$ a contemporaneous newspaper account was more accurate than present oral testimony which, even if available, inevitably would be clouded and distorted by the passage of many years. Moreover, sincerity was strongly assured in the instant case because the declaration apparently was made with no improper motive. ${ }^{27}$ Finally, the reporting of such an event

circumstances which tend to guarantee trustworthiness. Especially significant in this respect is the majority rule requirement that a declarant as to family pedigree be a member of the family. E.g., Barsotti v. Bertolino, I2 I N.J. Eq. 346, 189 Atl. 659 (1937). The minority role requires an "intimate relationship." UNIFORM RULE OF EVIDENCE $63(24) ; 5$ WIGMORE $\S 1487$. This seems the preferable view in nodern society where one's close friends often know more of his pedigree than his relatives.

${ }^{20}$ The use of the article as evidence instead of the testimony of the author constituted hearsay. Moreover, the article was anonymous, and the defendant conceded that the identity of the author was not known. Supplemental Brief for Appellee, p. 2 I. Thus, there was no way of knowing whether the reporter wrote the story from his own personal knowledge or from information obtained from eyewitnesses. If the latter was the case, a problem of "double hearsay" is present.

Each "step" of hearsay within a chain thereof must come under some exception for the evidence to be admissible. UNIFORM RULE of Evidence 66. Undter the approach taken in the Dallas County case, however, it would seem that admissibility on the grounds of necessity and trustworthiness either simultaneously satisfies or eliminates this requirement.

${ }^{27}$ Obviously, the article was not written with the motive of misleading a jury fifty 
in a community newspaper was a declaration made under such circumstances of notoriety as to have dissuaded any attempt at misrepresentation by the writer.

The narrow holding of the Dallas County case-that old local newspapers may under proper circumstances be admitted as proof of longpast community events-can be greatly utilized in future trial practice, simplifying the introduction of relevant evidence. More importantly, however, the decision indicates the sound result that can be achieved by application of the standards of necessity and trustworthiness in those cases where the extension of traditional hearsay exception labels is neither an appropriate nor an adequate ground for determining admissibility. This latter aspect of the Dallas County case is of particular significance and especially merits commendation.

years later; it is possible, however, that a present oral witness might have been so motivated. 